\title{
THE CONSERVATION STATUS OF FRESHWATER MACRO-INVERTEBRATES IN THE BUCKLAND MILITARY TRAINING AREA, SOUTHEASTERN TASMANIA
}

\author{
by Pierre Horwitz and Jane Andrew
}

(with three tables and one text-figure)

HORWITZ, P. \&ANDREW, J., 1992 (31:x): The conservation status offreshwater macro-invertebrates in the Buckland Military

Training Area, southeastern Tasmania. Pap. Proc. R. Soc. Tasm. 126: 101-108. https://doi.org/10.26749/rstpp.126.101

Centre for Environmental Studies, University of Tasmania, GPO Box 252C, Hobart, Tasmania 7001; (PH now Edith Cowan

University, Joondalup Drive, Joondalup WA, Australia 6027).

The freshwater macro-invertebrate fauna of the Buckland Military Training Area near Triabunna on the east coast of Tasmania was investigated in April 1991. A total of 97 taxa were identified from ten sites, of which only about half could be assigned to species level and given a conservation status. Only one of these was deemed significant from a conservation viewpoint; at least eight others plus all the unknown species require further investigation to clarify their status.

About half of the species were found at only one site; the most similar sites were from permanent water at lower altitudes (although in different catchments). Species from lowland sites were well known and could be readily identified (often having broad distributional ranges over southeastern Australia). The upland site from a rainforest creek contained a high proportion of species not found elsewhere in the study, as did other upland temporary water bodies. Inrroduced fish and forestry activity are likely to represent the most serious threats to the faunal assemblage in the area.

Key Words: macro-invertebrates, freshwater fauna, Tasmania.

\section{INTRODUCTION}

Tasmania is widely recognised as a haven for freshwater fauna, particularly those species adapted to cool conditions but there is a great deal of climatic variation within the state. The eastern half is conspicuously drier than the western half. Eastern Tasmania has small pockets of wetter areas, and this topographical variability is translated into habitat variation for freshwater organisms. Superimposed on this is a considerable amount of degradation and alteration of the original character of the area since the European invasion.

Within this widespread degraded and altered habitat, the Buckland Military Training Area (BMTA) has remained relatively intact, with only parts of the area having been disturbed by clear fell and hot burn logging activity, some grazing, military operations and recreational activities. The BMTA has a range of freshwater habitats over an altitudinal range of about $600 \mathrm{~m}$, including Sphagnum or heathy swamps, temporary and permanent creeks in dry sclerophyll, wet sclerophyll or rainforested areas, and artificial impoundments (fire dams). The BMTA lies some $80 \mathrm{~km}$ by road from Hobart, north and northwest of Buckland, Orford and Triabunna, where it occupies an area of approximately $15 \mathrm{~km} \times 21 \mathrm{~km}$. The present work was part of a broader study aimed at describing the flora, fauna, geology, soils and archaeology of the BMTA, as part of an environmental impact assessment and land management plan for the Department of Defence (Hepper de Gryse Team 1991).

Prior to this work the BMTA had not been surveyed for its freshwater invertebrate assemblages, and there are, as yet, no available studies on these assemblages for any part of southeastern Tasmania. There is some ongoing work at the Tasmanian Inland Fisheries Commission on the feeding requirements of trout and the swan galaxias (Galaxias fontanus) (in the Swan and Macquarie Rivers), and three Honours students at the University of Tasmania have worked in the area.
Of these, Bennison (1975) found that the Coal River, west of the BMTA, could be divided longitudinally into two zones: a lower region (potamon; altitude 110-20 m) and an upper region (rhithron; altitude 445-110 m). Invertebrates such as amphipods, caddis-flies, mayflies and some snail species were characteristic of upper reaches, whilst some snail species, dragonflies and water mites were characteristic of the lower region.

The aim of the present study was to undertake a "snapshot" survey of the BMTA over a range of habitats, in order to (1) provide an inventory of freshwater invertebrate species for the BMTA,

(2) determine, where possible, the conservation status of the species, and

(3) estimate the impacts of various activities (military operations, forestry, grazing etc.) on the fauna.

\section{METHODS}

In addition to the variety of aquatic and semiaquatic habitats over its altitudinal range, the BMTA crosses several catchments, being drained by tributaries of the Prosser River in the south (Bluff River and Back River), Little Swanport River in the north (Pine Rivulet, Pepper Creek and Mitchelmores Creek), and Maclaines Creek and Ravensdale Rivulet in the east (fig. 1). In order to sample as much of the geographic variability as possible, sites were selected to include the aquatic faunas of each of the major drainages, at a range of altitudes and in different habitats. There were ten sampling sites in all. Five were from temporary pools in creeks in headwater regions, including one marsh (recently burnt), the pools in the headwaters of three creeks, and one creek in rainforest (sites 1-5). Four were chosen from the lowland sections of rivers, three from flowing, rocky sections, and one from amongst emergent vegetation adjacent to a deep pool in the channel of one of the rivers (sites 6-9). The final site was an anthropogenic water source (a fire dam, 


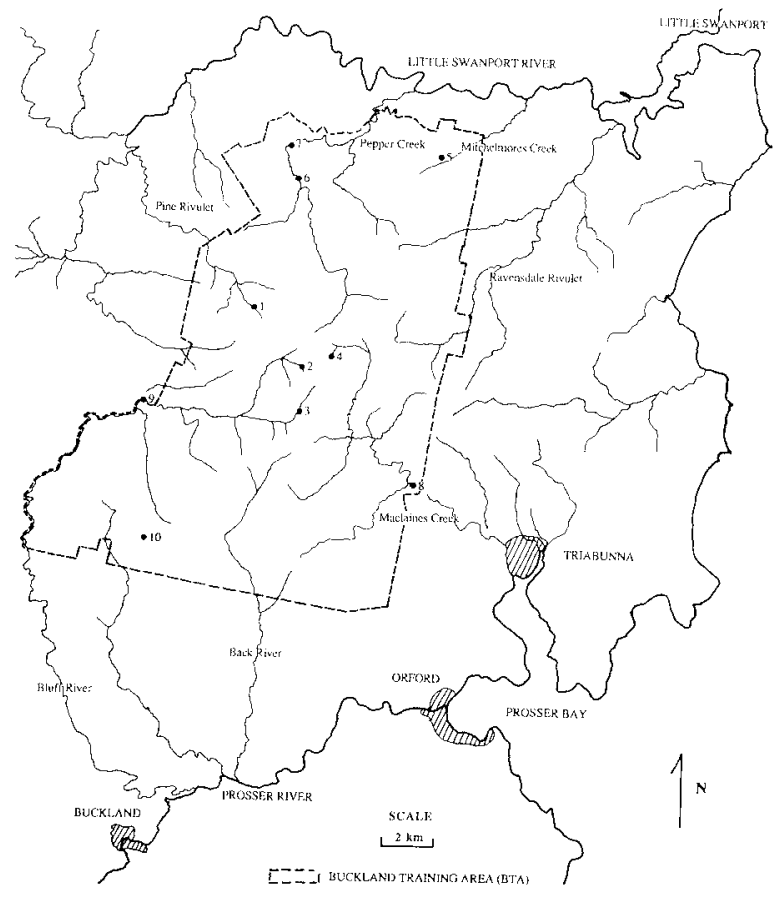

site 10). The locations of the sites are given in figure 1 .

Sites 1-4 were sampled on 15 April 1991, sites 5-7 on 16 April, and sites 8-10 on 17 April 1991.

At each site, a Freshwater Biological Association net of mesh pore size $0.95 \mathrm{~mm}$ was used to collect freshwater invertebrates from one ot more of four categories:

(1) amongst submerged leaf litter (and other organic debris),

(2) amongst submerged riparian vegetation, where it overhung the water,

(3) amongst submerged and emergent aquatic vegetation,

(4) on the surface of rocks (by gently brushing and washing them).

Samples from each microhabitat were combined for each site and were washed into a plastic bag for transportation. Each sample was rinsed in tap water and washed through a sieve of $500 \mu \mathrm{m}$ mesh pore size, before being sorted in a white tray within 12 hours of collection. Invertebrates were preserved in $75 \%$ ethanol, and later identified to species level where possible.

FIG. 1 - Location of the ten sampling sites in the Buckland Military Training Area on the east coast of Tasmania.

Table 1

Sites sampled within the BMTA

\begin{tabular}{|c|c|c|c|c|c|}
\hline Site & Location & Site description & $\begin{array}{c}\text { Water } \\
\text { Permanence* }\end{array}$ & $\begin{array}{l}\text { Altitude }{ }^{\dagger} \\
\text { Category } \\
\quad(\mathrm{m})\end{array}$ & $\begin{array}{l}\text { Microhabitat } \\
\text { Category } \\
\text { Sampled }\end{array}$ \\
\hline 1 & Dolans Marsh & $\begin{array}{l}\text { Small pools in a narrow channel of a marsh; clear water } \\
\text { pools with thick fibrous algal growths, site burnt three } \\
\text { months prior to sampling. }\end{array}$ & $\mathrm{T}$ & $\mathrm{U}(430)$ & 1,3 \\
\hline 2 & Bluff R. & $\begin{array}{l}\text { Small rocky turbid pool in headwaters of river, } \\
\text { fed by a small trickle, in regeneration area }\end{array}$ & $\mathrm{T}$ & $\mathrm{U}(435)$ & $1,2,4$ \\
\hline 3 & Baldy Ck & $\begin{array}{l}\text { Small rocky creek with clear flowing water in rain- } \\
\text { forest in headwaters of Baldy Ck (Bluff River). }\end{array}$ & $\mathrm{T}$ & $\mathrm{U}(425)$ & 1,4 \\
\hline 4 & Madaines Ck & $\begin{array}{l}\text { Small rocky turbid pool in headwaters of creek, } \\
\text { fed by a small trickle which becomes subterranean } \\
\text { downstream. Regeneration Area. }\end{array}$ & $\mathrm{T}$ & $\mathrm{U}(450)$ & $1,2,4$ \\
\hline 5 & Mitchelmores $\mathrm{Ck}$ & Tributary of creek, pool with clear water in rocky creek. & $\mathrm{T}$ & $\mathrm{L}(160)$ & 1,4 \\
\hline 6 & Pepper Ck & $\begin{array}{l}\text { Rocky pools with clear running water in gorge of creek. } \\
\text { Aquatic vegetation Myriophylium salsugineum. }\end{array}$ & $\mathrm{P}$ & $\mathrm{L}(175)$ & $1,2,3,4$ \\
\hline 7 & Pepper Ck & $\begin{array}{l}\text { Deep }(>1 \mathrm{~m} \text { ) darkish pool in slow flowing part of creek, } \\
\text { aquatic vegetation including Typha sp., Eleocharis acuta, } \\
\text { Myriophyllum aquaticum, Potamogeton tricarinatus. }\end{array}$ & $\mathrm{P}$ & $\mathrm{L}(120)$ & 3 \\
\hline 8 & Maclaines $\mathrm{Ck}$ & Rocky pools with clear running water. & $\mathrm{P}$ & $\mathrm{L}(90)$ & $1,2,4$ \\
\hline 9 & Bluff R. & $\begin{array}{l}\text { Slimy rocks in long pools of river, with clear running } \\
\text { water. Aquatic vegetation Myriophyllum simulans. }\end{array}$ & $P$ & $\mathrm{~L} ?(280)$ & $1,2,4$ \\
\hline 10 & Fire Dam & $\begin{array}{l}\text { Slightly turbid fire dam near Sphagnum bog. Aquatic } \\
\text { vegetation including Scirpus fluitans, Ranunculus rivularis, } \\
\text { Elatine gratioloides. }\end{array}$ & $P ?$ & U? $(360)$ & 1,2 \\
\hline
\end{tabular}

${ }^{*} \mathrm{~T}=$ temporary, $\mathrm{P}=$ permanent $;{ }^{\dagger} \mathrm{U}=$ upland, $\mathrm{L}=$ lowland; ${ }^{\frac{*}{*}}$ see text. 
The characteristics, estimated altitudes and microhabitat categories (as above) of each site are given in table 1.

Physico-chemical characteristics of the water were measured on site. The water temperature for upland sites (sites $1-4$ ) was $8.0-11.5^{\circ} \mathrm{C}$; for remaining sites, temperatures varied between 9.5 and $12.7^{\circ} \mathrm{C}$. The $\mathrm{pH}$ of the water at the sampling sites was between 7.2 and 7.8. Conductivity values were more variable: upland sites 2,3 , and 4 , and the fire dam (site 10) had K18 values of $200 \mu \mathrm{S} / \mathrm{cm}$ or lower; upland site 1 had a value of over $500 \mu \mathrm{S} / \mathrm{cm}$, presumably because the area had just been burnt and recent rain had fallen; lowland sites had K18 values of between 230 and $1300 \mu \mathrm{S} / \mathrm{cm}$.

From information in the literature, each taxon was assigned a conservation status; categories chosen included those used by the IUCN (Wells et al. 1983: Rare, Vulnerable, Endangered, Indeterminately Threatened $[\mathrm{I}]$, and potentially threatened or Insufficiently Known [K]). For the purposes of this study the status of "Unknown" (U) was applied to taxa for which a species identification was not possible and/ or for which distributional information was unavailable. Similarly the status of "Apparently Not Threatened" (ANT) was applied to species which were not described in the literature as being rare or uncommon, did not appear in a review of the conservation of Tasmanian invertebrates (Greenslade, in press), nor were named in a recent census (involving taxonomic experts) of threatened invertebrates in Tasmania conducted by Horwitz \& Smith.

No attempt was made to estimate the abundance levels of taxa. For organisms identified to species level, estimates of distribution were made (either found in southeastern Australia [SEA], endemic to Tasmania [END] or endemic to southeastern Tasmania [SET]).

Sites were compared by

(1) estimating species richness by summing the number of species found at each site,

(2) undertaking site comparisons by constructing a table of similarities based on the presence of the same taxa at each site (coefficient of similarity), and

(3) calculating the number of species that were found exclusively at each site (number of local endemics).

\section{RESULTS}

An inventory of the freshwater macro-invertebrate species found in the BMTA is given in table 2, showing the presence of taxa at each site.

Most of the major groups of freshwater invertebrate species were represented in the BMTA. Ninety-seven taxa were recorded during the survey, representing at least this many species. Distributional and taxonomic information for many of the taxa was not available in the literature; thus, 50 taxa are designated as having an unknown conservation status ("U" in table 2).

The remaining 47 species were deemed to be sufficiently understood to make judgements about their conservation status. None of them are known to have been introduced to Tasmania or to the BMTA, although the 18 taxa which were found in the fire dam have had their local distributions extended by the creation of such impoundments.

Thirty-eight species (81\% of the 47 well-understood species) are apparently not threatened (in Tasmania). Of these species:
(1) many occur throughout at least southeastern Australia (refer to table 2),

(2) comparatively few are Tasmanian endemics, these endemics include the phreatoicid shrimps, the water pennies Sclerocyphon aquaticusand S. secretus, the stoneflies Leptoperla varia and Eusthenia spectabilis, and the damselfly Ischnura beterosticta tasmanica).

\section{Significant Species}

None of the 47 species could be placed into the categories of Rare, Vulnerable or Endangered; however, there are nine species in the BMTA which are or could be of significance from a conservation viewpoint:

(1) the snail Fluvidona sp., which is found throughout eastern Tasmania but may well contain locally restricted species or genotypes (given the occurrence of the latter for other members of the genus; W. Ponder, pers. comm.); no information is known about the species collected in the BMTA, except that the snails were recorded at four of the nine sites, three lowland rivers and one temporary creek;

(2) a water bug found in the rainforest creek which belongs to the genus Microvelia but did not conform to any of the species known to occur in Tasmania (determined from a key to Tasmanian species made available by Lansbury \& Lake); these are, therefore, either variants of previously described species, or species which have not previously been found in Tasmania, or a new species;

(3) the water bug Agraptocorixa parvipunctata, which is reported to be uncommon in Tasmania (Lansbury \& Lake, unpubl.); this was found in the fire dam and in a lowland water course;

(4) the water beetles Carabhydrus niger and Australphilus saltus, both known from very few localities in Tasmania (Horwitz, unpubl., Watts, 1978); these were found amongst vegetation in the fire dam, and in a lowland water course; (5) the mayfly genus Koorrnonga, found at six sites, which is not otherwise known from eastern Tasmania (possibly due to the lack of knowledge of the mayfly fauna of eastern Tasmania; S. Chilcott, pers. comm.);

(6) the dragonfly Austroaeschna tasmanica, which is endemic to Tasmania and considered to be uncom mon and vulnerable to disturbance (Allbrook, pers. comm.); it was found amongst submerged vegetation in a lowland water course;

(7) the damselfly Austrolestes io, which is found in southeastern Australia but considered to be uncommon in Tasmania (Allbrook 1979); this was found in the fire dam and two lowland water courses;

(8) the mecopteran belonging to the genus Nannochorista, which has not previously been found in eastern Tasmania; it was found only at the rainforest creek.

Each of the species described above (with the exception of Austroaeschna tasmanica) has been referred to for the purposes of this study as being "insufficiently known". Several sites contained three or more of these important species, for instance, the rainforest creek (site 3, four species), a slowflowing lowland water course (site 7, four species), and the fire dam (site 10, three species). 
Table 2 Inventory of freshwater macro-invertebrate species found in the BMTA

Shows the common names of the major taxonomic groups, the species designation, the presence $(\mathrm{x})$ of each species from each site and the total species present at each site. Codes for the conservation status and the distribution are given under "Methods" above.

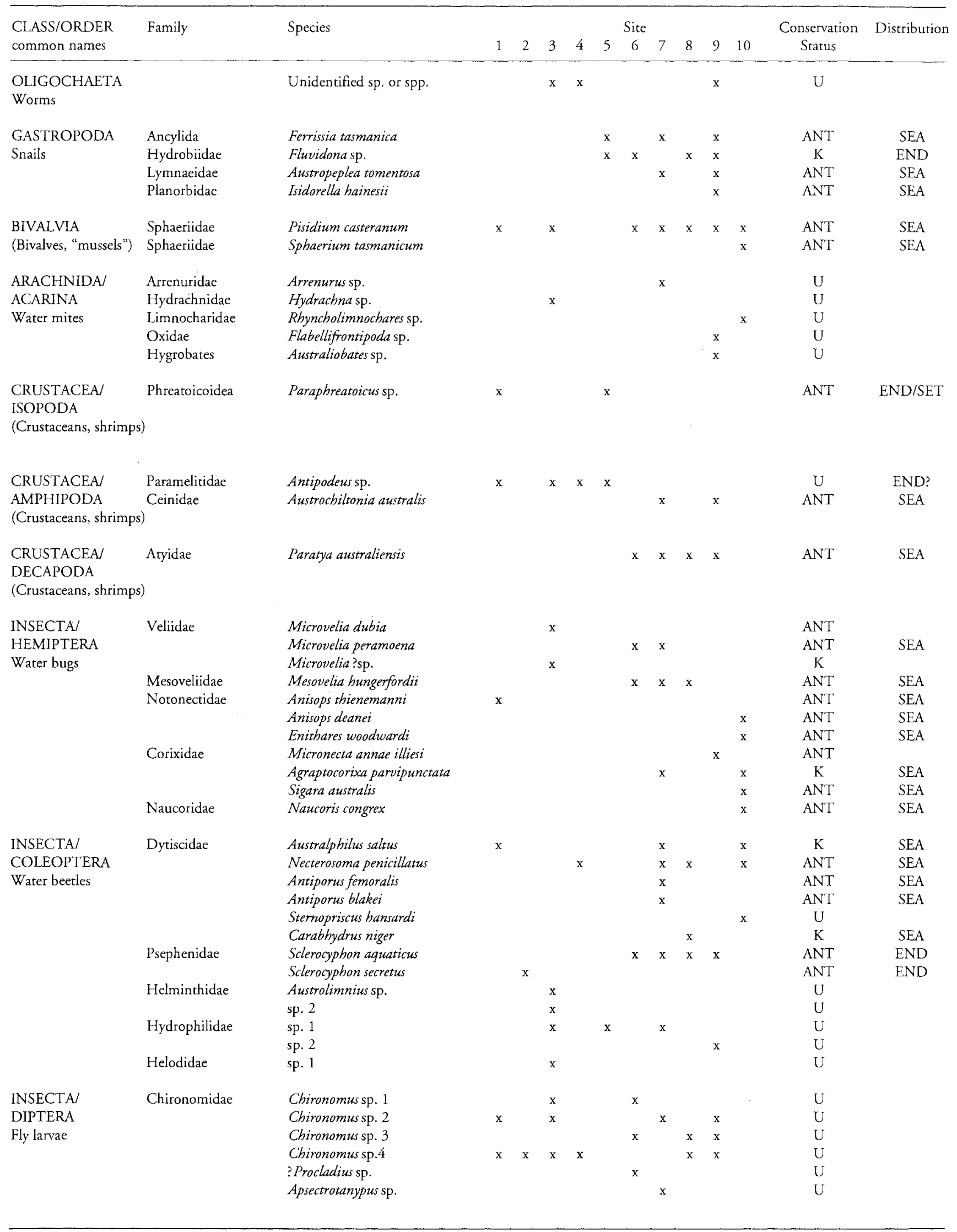


Table 2 cont.

\begin{tabular}{|c|c|c|c|c|c|c|c|c|c|c|c|c|c|c|}
\hline $\begin{array}{l}\text { CLASS/ORDER } \\
\text { common names }\end{array}$ & Family & Species & 1 & 2 & 3 & 4 & 5 & $\begin{array}{l}\text { Site } \\
6\end{array}$ & 7 & 8 & 9 & 10 & $\begin{array}{c}\text { Conservation } \\
\text { Status }\end{array}$ & Distribution \\
\hline & Ceratopogonidae & sp. 1 & & & $\mathrm{x}$ & & & $\mathrm{x}$ & & $\mathrm{x}$ & $\mathrm{x}$ & & $\mathrm{U}$ & \\
\hline & Culicidae & (Culicini) & $\mathrm{x}$ & & $x$ & $\mathrm{x}$ & $\mathrm{x}$ & $\mathrm{x}$ & $\mathrm{x}$ & & & & $\mathrm{U}$ & \\
\hline & & (Anophelini) & & & $\mathrm{x}$ & $\mathrm{x}$ & & & & & & & $\mathrm{U}$ & \\
\hline & Dixidae & Dixa sp. & & & & & & $\mathrm{x}$ & $\mathrm{x}$ & $\mathrm{x}$ & & & $\mathrm{U}$ & \\
\hline & Simuliidaè & ?Austrosimulium sp. & & & & & & & & & $\mathrm{x}$ & & $\mathrm{U}$ & \\
\hline & Tipulidae & sp. 1 & & & $\mathrm{x}$ & & & & & & & & $\mathrm{U}$ & \\
\hline & Athericidae & sp. 1 & & & $x$ & & & & & & & & $\mathrm{U}$ & \\
\hline \multirow{5}{*}{$\begin{array}{l}\text { INSECTA/ } \\
\text { PLECOPTERA } \\
\text { Stoneflies }\end{array}$} & Gripopterygidae & Trinotoperla sp. & & & $\mathrm{x}$ & & & & & & & & & \\
\hline & & Leptoperla varia & & & & & & $\mathrm{x}$ & & & & & ANT & END \\
\hline & & Dinotoperla bassae & & & & & & $x$ & $\mathrm{x}$ & & $\mathrm{x}$ & & ANT & SEA \\
\hline & Eustheniidae & Eusthenia spectabilis & & & & & & & & & $\mathrm{x}$ & & ANT & END \\
\hline & Notonemouridae & Austrocercoides sp. & & & $\mathrm{x}$ & & & & $x$ & & $\mathrm{x}$ & & $\mathrm{U}$ & \\
\hline \multirow{7}{*}{$\begin{array}{l}\text { INSECTA/ } \\
\text { EPHEMEROPTERA } \\
\text { Mayflies }\end{array}$} & Leptophlebiidae & Koormonga sp. & & & $\mathrm{x}$ & $\mathrm{x}$ & & $\mathrm{x}$ & $\mathrm{x}$ & $\mathrm{x}$ & $\mathrm{x}$ & & $\mathrm{K}$ & \\
\hline & & Nousia sp. & & & $x$ & $x$ & $\mathrm{x}$ & $x$ & & & $\mathrm{x}$ & & U & \\
\hline & & Atalophlebia australis & & & & & & & $\mathrm{x}$ & & $\mathrm{x}$ & & ANT & SEA \\
\hline & & Atalophlebia albiterminata & & & & & & & & & $\mathrm{x}$ & & ANT & SEA \\
\hline & & Genus D (J. Dean) & & & & $\mathrm{x}$ & & & & & $x$ & & $\mathrm{U}$ & \\
\hline & Baetidae & ?Baetis sp. & & & & & & & & & $\mathrm{x}$ & & $\mathrm{U}$ & \\
\hline & Caenidae & Tasmanocoenis sp. & & & & $\mathrm{x}$ & & $\mathrm{x}$ & $\mathrm{x}$ & $\mathrm{x}$ & $\mathrm{x}$ & & $\mathrm{U}$ & \\
\hline \multirow{5}{*}{$\begin{array}{l}\text { INSECTA/ } \\
\text { ODONATA } \\
\text { Dragonflies }\end{array}$} & Aeshnidae & Austroaeschna parvistigma & & $\mathrm{x}$ & & & & $\mathrm{x}$ & & $\mathrm{x}$ & & & ANT & SEA \\
\hline & & Austroaeschna tasmanica & & & & & & & $\mathrm{x}$ & & & & I & END \\
\hline & & Aeshna brevistyla & & & & & & & $\mathrm{x}$ & & & & ANT & SEA \\
\hline & Gomphidae & Austrogompbus guerini & & & & & & $x$ & & $\mathrm{x}$ & & & ANT & SEA \\
\hline & Cordulidae & Hemicordulia tau & & & & & & & $\mathrm{x}$ & & & $\mathrm{x}$ & ANT & SEA \\
\hline \multirow[t]{4}{*}{ Damselflies } & Lestidae & Austrolestes io & & & & & & & $\mathrm{x}$ & & $\mathrm{x}$ & $\mathrm{x}$ & K & SEA \\
\hline & & Austrolestes analis & & & & & & & $\mathrm{x}$ & & $\mathrm{x}$ & $\mathrm{x}$ & ANT & SEA \\
\hline & Coenagrionidae & Ischnura beterosticta tasmanica & & & & & & & $\mathrm{x}$ & & & & ANT & END \\
\hline & & Coenagrion lyelli & & & & & & & $\mathrm{x}$ & & & $\mathrm{x}$ & ANT & SEA \\
\hline \multirow{22}{*}{$\begin{array}{l}\text { INSECTA } \\
\text { TRICHOP'TERA } \\
\text { Caddis flies }\end{array}$} & Leptoceridae & sp. 1 & & $\mathrm{x}$ & $x$ & & & & & & & & $\mathrm{U}$ & \\
\hline & & sp. 2 & & & $\mathrm{x}$ & & & & & & & & $\mathrm{U}$ & \\
\hline & & sp. 3 & & & $\mathrm{x}$ & $\mathrm{x}$ & & & $\mathrm{x}$ & $\mathrm{x}$ & $\mathrm{x}$ & $\mathrm{x}$ & $\mathrm{U}$ & \\
\hline & & sp. 4 & & $\mathrm{x}$ & & $\mathrm{x}$ & & $\mathrm{x}$ & & & & $x$ & $\mathrm{U}$ & \\
\hline & & sp. 5 & & & & & & $\mathrm{x}$ & $\mathrm{x}$ & $\mathrm{x}$ & $\mathrm{x}$ & & $\mathrm{U}$ & \\
\hline & & sp. 6 & & & & & & $\mathrm{x}$ & $\mathrm{x}$ & $\mathrm{x}$ & $\mathrm{x}$ & $\mathrm{x}$ & $\mathrm{U}$ & \\
\hline & & sp. 7 & & $\mathrm{x}$ & & & & & & & & & $\mathrm{U}$ & \\
\hline & & sp. 8 & & & & & & & $\mathrm{x}$ & $\mathrm{x}$ & & & $\mathrm{U}$ & \\
\hline & & sp. 9 & & & & & & & $\mathrm{x}$ & & & & $\mathrm{U}$ & \\
\hline & Calocidae & Caenota plicata & & $\mathrm{x}$ & $\mathrm{x}$ & & & & & & & & ANT & SEA \\
\hline & & Tamasia variegata & & & & & & $\mathrm{x}$ & & & $\mathrm{x}$ & & ANT & SEA \\
\hline & Tasimiidae & Tasimiasp. & & & $\mathrm{x}$ & & & & & $\mathbf{x}$ & & & U & \\
\hline & Helicopsychidae & Helicopsyche sp. & & & & & & $\mathrm{x}$ & & $\mathrm{x}$ & & & $\mathrm{U}$ & \\
\hline & Atriplectididae & Atriplectides dubius & & & & & & & $\mathrm{x}$ & & & & ANT & SEA \\
\hline & Odontoceridae & Marilia bola & & & & & & & & & & & $\mathrm{U}$ & \\
\hline & Polycentropididae & Genus I sp. 3 & & & & & & $\mathrm{x}$ & & $\mathrm{x}$ & & & $\mathrm{U}$ & \\
\hline & & Plectrocnemia sp. & & & & $\mathrm{x}$ & & $\mathrm{x}$ & $\mathrm{x}$ & & $\mathrm{x}$ & & $\mathrm{U}$ & \\
\hline & Ecnomidae & Ecnomus tillyardi & & & & & & & & $\mathrm{x}$ & & & ANT & SEA \\
\hline & & Ecnomina F ?sp. 7 & & & & & & & & $\mathrm{x}$ & $\mathrm{x}$ & & $\mathrm{U}$ & \\
\hline & Hydrobiosidae & sp. 1 & & & & & & & & $\mathrm{x}$ & & & $\mathrm{U}$ & \\
\hline & Hydroptilidae & Hellyethira simplex & & & & & & & $\mathrm{x}$ & & & & $\mathrm{U}$ & SEA \\
\hline & & Hellyethirasp. 2 & & & & & & & $\mathbf{x}$ & & & & $\mathrm{U}$ & \\
\hline \multirow{2}{*}{$\begin{array}{l}\text { INSECTA / } \\
\text { MECOPTERA }\end{array}$} & Nannochoristidae & Nannochorista sp. & & & $\mathrm{x}$ & & & & & & & & $\mathrm{K}$ & \\
\hline & TOTAL NUMBE & F SPECIES & 8 & 7 & 28 & 13 & 7 & 26 & 40 & 25 & 36 & 18 & & \\
\hline
\end{tabular}




\section{Site Differences}

Species richness varied considerably between sites (see Total Number of Species, table 2). Upland sites (sites 1,2 and 4) and the temporary pool in the creek at site 5 yielded between seven and 13 species per site. In contrast, 28 species were recorded from the rainforest creek (the upper reaches of Baldy Creek, site 3), and between 25 and 40 species were recorded from lowland water courses (sites 6-9). Eighteen species were recorded from the fire dam. Site 7 , the slowflowing lowland water course, contained the highest species richness.

The similarities between each two sites, in terms of presence or absence of invertebrate taxa, and local endemicity are shown in table 3 . Several features of interest can be discerned from the data:

(1) The lowland rivers and creeks (sites 6-9), although in separate water catchments, have comparatively high levels of species similarity, ranging from $22-48 \%$. The highest level of similarity in the study was found between sites 6 and 8 (Pepper Creek and Maclaines Creek), despite the distance separating these creeks.

(2) The upland sites had relatively low levels of similarity with the lowland rivers and creeks. This is exemplified by sites 1 and 2, which have levels of similarity of $0-8 \%$ with sites 6-9. Eight odonatan species, four water beetles (Dytiscidae), three stonefly species, the shrimp Paratya australiensis and the amphipod Austrochiltonia australis were absent from upland sites.

(3) Eleven species were only found at the rainforest creek (site 3). Taxa which contributed to this high level of local endemicity were three water beetles, a caddis fly, two dipterans and a mecopteran larva, a water mite and a stonefly.

(4) The fire dam (site 10) had a faunal assemblage of which seven species were not found at any other site, including four water bugs, a bivalve, a water mite and a water beetle.

Table 3

Similarity indices between sites* and number of locally endemic species ${ }^{\dagger}$.

\begin{tabular}{lllllllllll}
\hline Site & 2 & 3 & 4 & 5 & 6 & 7 & 8 & 9 & 10 & $\begin{array}{c}\text { Number of } \\
\text { "Local } \\
\text { Endemics" }\end{array}$
\end{tabular}

\begin{tabular}{lcccccccccc}
\hline 1 & 9 & 16 & 17 & 25 & 6 & 7 & 6 & 8 & 9 & 1 \\
2 & - & 9 & 12 & 0 & 6 & 0 & 7 & 0 & 9 & 2 \\
3 & - & - & 24 & 13 & 10 & 8 & 13 & 16 & 5 & 11 \\
4 & - & - & - & 18 & 18 & 12 & 15 & 15 & 11 & 0 \\
5 & - & - & - & - & 10 & 7 & 3 & 8 & 0 & 0 \\
6 & - & - & - & - & - & 24 & 48 & 24 & 7 & 2 \\
7 & - & - & - & - & - & - & 22 & 22 & 20 & 11 \\
8 & - & - & - & - & - & - & - & 27 & 10 & 3 \\
9 & - & - & - & - & - & - & - & - & 10 & 9 \\
10 & - & - & - & - & - & - & - & - & - & 7 \\
\hline
\end{tabular}

* i.e., \% of species which two sires share.

$\dagger$ i.e., found nowhere else in this survey.

₹ For site descriptions, see table 1. Total number of species, 97.

\section{DISCUSSION}

The freshwater fauna list described herein for the BMTA is affected by both the time of the year in which the survey was undertaken (a three-day period in April) and the method used to collect the samples.

It is quite likely that the same invertebrate sampling technique would have produced a different species list, if the sampling had been undertaken in a different season. These differences arise because, at any time of year, there will be species undergoing a part of their life cycle which means they are unlikely to be caught by a net. Similarly, the net mesh pore size means that freshwater animals of length or diameter less than $1 \mathrm{~mm}$ will be unlikely to be collected. Furthermore, since sampling effort was limited, the absence of a taxon from a sample does not necessarily mean that the taxon was absent from the site at the time of sampling.

These factors will tend to render too low the number of invertebrate species in the area as listed here. Encountering taxa which cannot be readily identified also exacerbates this problem. For all these reasons, the species list given in this report must not be interpreted as being complete.

\section{Conservation Status of Freshwater Fauna}

The invertebrate assemblage contains representatives of most major taxonomic groups which one would expect from southeastern Tasmania. In this respect, the assemblage is similar to that described for the Coal River (Bennison 1975) and from farm dams near Copping (Walker 1974, Blake 1991).

From the 47 species found in the BMTA for which a conservation status could be assigned, only one was regarded as being threatened and warranting special concern within the area. Otherwise, there appear to be no species which, by their rarity or susceptibility to extinction, should constrain activities within the BMTA. This conclusion must, however, be considered in the light of the limitations described above; there may be species which have not been found in this survey which are indeed threatened.

It should aiso be borne in mind that the well-known species are likely to be more common and, therefore, not rare or otherwise threatened. Our concern should be for those species which were assigned an "Unknown" status in the study, and more work is required to establish the taxonomic identity and status of these species.

The one species recognised as "indeterminately threatened", the dragonfly Austroaeschna tasmanica, is endemic to Tasmania, where it is uncommon and has had its range of available habitat reduced by clearing of riparian vegetation which overhangs the water (Allbrook 1979). Under these conditions it is replaced by the congeneric $A$. parvistigma. The presence of both species in the BMTA reinforces the need to avoid clearing of overhanging vegetation, to stabilise eroded or undercut banks, and to maintain riparian strips during forestry activity.

Three of the nine species recognised in this survey as being of conservation significance were found in a fire dam. In addition, $39 \%$ of the fauna in the fire dam were not recorded from any other site. Thus, artificial impoundments can provide an extra habitat or a refuge under conditions of stress for some local species, but also an opportunity for invasion by species not native to the area. The presence of dams, therefore, raises conservation issues in its own right. 
The potential for dams to harbour rare or threatened freshwater fauna has been recorded from elsewhere in the world (e.g. dragonflies in South Africa; Samways 1989). Fire dams, as such, represent something of a quandary for the management of the BMTA, since they require special treatment for their fauna, yet the water in them may be required for control of fires.

The differences observed between lowland sites and upland sites in terms of the presence of species support the notion of longitudinal zonation for river systems in southeastern Tasmania (as described for the Coal River by Bennsion 1975). On the basis of these site comparisons, the rainforest and the slow-flowing lowland sites were recognised as being important, with high proportions of species which were not found at other sites.

It should be noted that the limitations on this set of data, caused by seasonal variation and limited sampling effort (as outlined above), would probably cause overestimates of site differences. On the other hand, taxonomically unresolved and closely related species, which separate by habitat or altitude, will be recorded as one species from two sites, when in actual fact they represent two or more species. Thus, differences between sites will be underestimated when using a parameter of species richness.

The rainforest creek is an example of an upland cool-cold clear stream. Such streams (whether permanent or temporary over summer) are of importance from a scientific point of view, because of the potential for them to harbour relictual faunas from periods in the past when the climate was cooler. This is particularly relevant in the BMTA, since eastern Tasmania is generally dry, and relict species are likely to occur only in isolated areas where they have survived the drying climate. There was a high level of local endemicity found for this site (11\%), even compared to a sample from $200 \mathrm{~m}$ lower down in the same catchment (site 9). The results suggest that such streams should be afforded protection in their own right. In the BMTA, the main threats to these streams and their fauna include logging and other forestry activity (see below).

The slow-flowing lowland portion of Pepper Creek (site 7) contained the highest species richness, and was also found to contain four of the invertebrate species which are important from a conservation viewpoint and eleven species which were not found elsewhere (table 3). The high species richness at this site may be a function of habitat diversity (since it contained logs and rocks on the creek bed, also macrophytic vegetation, and was fed by a flowing creek). These microhabitats present excellent areas for predator avoidance (see below)

\section{Introduced Fish}

Eight freshwater fish species have been recorded for the BMTA and, of these, four are non-native (brown and rainbow trout, redfin perch and tench; Hepper de Gryse Team 1991). Brown trout were recorded from sites $6,7,8$ and 9 in this study. The feeding habits of introduced fish species represent a threat to native invertebrate assemblages and also to other native fish species. For instance, brown trout are considered to represent the most serious threat to the continued survival of the swan galaxiid (Sanger \& Fulton 1991). Brown trout in Victoria have been shown to feed selectively on native galaxiid species until the prey numbers drop, after which they feed on selected invertebrate groups, changing the proportional representation of these in the community (Fletcher 1986). Research into the effects of trout on invertebrates in Tasmanian waterways has not been undertaken, despite numerous demonstrations that trout feed on important species, and repeated calls for the research to be done (see Horwitz 1990).

The high proportion of introduced fish in the BMTA ( 4 out of 8 species present) has undoubtedly already affected the nature of the faunal assemblages in the area. The disturbance to native freshwater communities by trout is probably the most serious alteration to the freshwater fauna in the BMTA since the Europeanisation of Tasmania.

\section{Other Threats to Freshwater Fauna}

The BMTA is subjected to a number of activities which have the potential to degrade freshwater habitats, in particular forestry, grazing and military operations.

Uncontrolled forestry activity has the potential to alter the composition of freshwater faunal assemblages by changing the hydrology, increasing sediment and nutrient loads, changing temperature regimes and energy inputs, channelising and altering the extent of woody material in water courses (Taylor 1990). The Draft Forest Practices Code (Forestry Commission of Tasmania 1989) should operate to minimise these and other impacts resulting from forestry activity.

In the BMTA, the issues of steep-country logging and logging in upland areas require consideration beyond those given in the Code as far as the freshwater fauna are concerned. Temporary creeks and pools in upland areas were found to contain elements of fauna which require protection. These habitats are generally classified as "Class 4 streams" by the Code and are given scant protection, resulting in the impacts outlined above. No riparian reserves are required, the only restriction being "no logging machinery within $10 \mathrm{~m}$ of the streambank except at defined crossing points" (Forestry Commission of Tasmania 1989: 35).

The extent of grazing in the BMTA should also be restricted, as grazing can affect waterways and the fauna in them by removing riparian vegetation, increasing nutrient loads, causing stream-bank erosion and increasing sediment input, thus potentially smothering benthic fauna, particularly those which rely on filter feeding mechanisms.

Military operations in the BMTA have the same potential to detrimentally affect freshwater faunas by physically and mechanically disturbing drainage lines, or creek and river beds and banks. The placing of explosives into waterways during military training activities obviously needs to be restricted, given that it is undoubtedly lethal to elements of the freshwater fauna (in particular fish, but it is also highly probable that frogs and invertebrates are affected as well).

\section{ACKNOWLEDGEMENTS}

The study formed part of a multidisciplinary assessment of the BMTA, which involved 18 specialist consultants representing over 15 professional disciplines, undertaken as part of an environmental impact assessment for the Department of Defence.

Identifications were made according to available keys for each group, except for selected groups (Hydrobiidae, Ephemeroptera, Phreatoicoidea and Acarina), which were 
identified by biologists familiar with them (Winston Ponder, Stuart Chilcott, Brenton Knott and Mark Harvey respectively). The identifications determined for the Odonata were verified by Piers Allbrook. Andrew Gibbons provided mounted slides of chironomid material.

\section{REFERENCES}

ALLBROOK, P., 1979: TASMANIAN ODONATA. Fauna of Tasmania Handbook no. 1, University of Tasmania.

BLAKE, G.M., 1991: The effects of habitat age and other factors on the structure of the pelagic community in some farm dams in Tasmania. Unpubl. B.Sc. Hons thesis, Univ. Tasm.

Bennison, G.L., 1975: An ecological method of classification of the Coal River in south-east Tasmania. Unpubl. B.Sc. Hons thesis, Univ. Tasm.

FLETCHER, A..R., 1986: Effects of introduced fish in Australia. In de Deckker, P. and Williams, W.D. (Eds): LIMNOLOGYIN AUSTRALLA: 231-238.

Forfstry Commission, Tasmania, 1989: DRAFT FOREST PRACTICES CODE. Forestry Commission, Hobart, Tasmania.

GREFNSIADE, P., in press: CONSERVATION PRIORITIES FOR TASMANIAN NON-MARINE INVERTEBRATES. Australian National Parks and Wildlife Service, Canberra, Australia.
Hepper de Gryse TeAm, 1991: ENVIRONMENTAL IMPACT ASSESSMENT, BUCKLAND TRAINING AREA AUSTRALIAN ARMY. Gth Military District, Hobart, Tasmania.

HORWITZ, P., 1990: CONSERVATION STATUS OFAUSTRALIAN FRESHWATER CRUSTACEANS. Australian National Parks and Wildlife Service Report Series 14. Canberra, Australia.

SAMWAYS, M.J., 1989: Farm dams as nature reserves for dragonflies (Odonata) at various altitudes in the Natal Drakensburg Mountains, South Africa. Biol. Conserv. 48: 181-188.

SANGER, A. \& Fulton, W., 1991: Conservation of endangered species of Tasmanian freshwater fish. Inland Fisheries Commission Occasional Report 91-01. Unpublished report, Hobart, Tasmania.

TAYLOR, R., 1990: FOREST PRACTICES FAUNA MANUAL. Forestry Commission, Tasmania.

WALKER, W. G., 1974: An investigation of farm dams in the Copping area of Tasmania. Unpubl. B.Sc. Hons thesis, Univ, Tasm.

WATTS, C.H.S., 1978: A revision of the Australian Dytiscidae (Coleoptera). Aust. J. Zool. Suppl. Ser. 57: 1-166.

Welis, S.M., PyLe, R.M. \& Colluns, N.M. (Eds.), 1983: THE IUCNINVERTEBRATE RED DATA BOOK International Union for the Conservation of Nature, Gland, Switzerland.

(accepted 18 September 1992) 